\title{
Investigating Academic Self-efficacy of University Students in Terms of Socio-demographic Variables ${ }^{i}$
}

\author{
Seydi Ahmet Satici ${ }^{1, *}$, Gurhan Can ${ }^{2}$ \\ ${ }^{1}$ Faculty of Education, Artvin Coruh University, Turkey \\ ${ }^{2}$ Faculty of Education, Yeditepe University, Turkey
}

Copyright $\bigcirc 2016$ by authors, all rights reserved. Authors agree that this article remains permanently open access under the terms of the Creative Commons Attribution License 4.0 international License.

\begin{abstract}
In this study whether academic self-efficacy of university students differ in terms of various socio-demographic features has been investigated. The study was conducted on 1679 students who were attending Anadolu University. In the study, the Academic Self-Efficacy Scale and Personal Information Form were used as data collection tools. In the analysis of the data, independent sample $t$ test and one-way analysis of variance were used. The findings of the study suggested that there are significant differences between academic self-efficacy, and gender, grade level, economic situation of the family, and perceived academic achievement. It was also suggested by the findings of the study that there are no significant differences between academic self-efficacy of university students, and field of study, education levels of the parents, number of family members and sibling numbers, perceived academic achievement in the high school, and the dwelling unit where the student lived the longest. Findings were discussed in line with relevant literature and conclusions were made.
\end{abstract}

Keywords Academic Self-efficacy, Socio-demographic Features, University Students

\section{Introduction}

Self-efficacy, defined as an individual's personal belief in his own capacities in order to produce a specific performance [1], has been observed from several perspectives in various fields. The fact that self-efficacy has been studied in various fields caused different concepts to appear in this field. Social self-efficacy [2], career self-efficacy [3], and technological self-efficacy [4] could be given as examples for these concepts. Moreover, academic self-efficacy, where individuals regulate the belief and justice themselves in different educational duties, on the other hand, appears to be a concept derived from self-efficacy theory of Bandura. Academic self-efficacy which defines individuals' beliefs of achievement of educational duties [5], affects learning and motivation, thus, would be helpful in students' mental efforts related to learning. In the improvement of academic self-efficacy, it is clear that different factors play important roles. Schunk and Pajeras [5] states that in shaping the academic self-efficacy, family, friends, school, and transitional influences are highly important. Additionally, it is also claimed that teachers' roles would add to shaping of student academic self-efficacy [6]. According to a study conducted by Banfield [7], teachers' negative behavior in class affected students' self-efficacy negatively. On the other hand, encouraging behaviors of teachers to students affected students positively in building self-efficacy. For instance, when a student who experienced failure in the classroom was given a positive feedback by the teacher, the self-efficacy of the student might gain strength, and this could help student to turn his failure into a success in the future [8]. Thus, Teachers need to be careful with their type of behavior and their feedback against their students for the sake of the academic self-efficacy of their students.

Academic self-efficacy, which reflects student's personal beliefs in his own capacities to achieve educational duties at expected levels [9], increases student's mental efforts to learning. Students whose academic self-efficacy levels are strong put persistent efforts to overcome the academic duties assigned to them and do not give up easily. Moreover, when students with higher academic self-efficacy are compared to the ones with low self-efficacy, it was found that those having higher academic self-efficacy study more, and by using efficient learning strategies, manage difficult academic duties effectively $[10,11,12]$. Studies showing that students with higher self-efficacy levels could manage their school life better are available in the literature $[10,13]$. Students with low levels of academic self-efficacy experience academic failure more, and have problems in devoting themselves to school [1]. In other words, students with low academic self-efficacy levels, draw themselves 
away from academic duties, show avoidance, experience motivation problems, and experience anxiety with school [14]. Nonetheless, students with high levels of self-efficacy devote themselves to school better, and be more optimistic [10]. Unsuccessful experiences of students affect their academic self-efficacy negatively. Bassi, Stace, Fave, Caprar [15] state that students with high self-efficacy are more willing to perform academic duties given to them when compared to the ones with low self-efficacy. Academic self-efficacy is also related with the vulnerability of students. Students with low academic self-efficacy, despite their ability levels, are more fragile in the classroom [16]. Since students with high academic self-efficacy are less fragile when compared to students with low academic self-efficacy, they tend to struggle fearlessly against failure in terms of their own beliefs. Academic self-efficacy is also beneficial for students to be positive individuals in social, emotional, and academic aspects [17]. It was confirmed that there is a significant relationship between academic self-efficacy of students and their adjustment levels $[9,18]$. Moreover, Nie, Lau and Lieau [19] stated that students whose academic self-efficacy is higher experience less academic stress and anxiety. In another study, conducted by Poyrazli et. al., [18], it was found that there is a negative relationship between academic self-efficacy and loneliness. There are also studies claiming that self-efficacy is closely related with problem behaviors. Chung and Elias [20] specified that the more the problem behaviors of the students are, the less their academic self-efficacy is. Similarly, Bandura [1] stated that students having low levels of academic self-efficacy fail to have strong relationships with their friends, and show more violent behaviors when compared to students with higher levels of academic self-efficacy. When students with higher academic self-efficacy perform weakly, they blame themselves for not putting enough effort, students with lower levels of academic self-efficacy, on the other hand, explain their failure through their own abilities [1].

When the literature is examined, it could be clearly seen that there is a strong, significant positive relationship between academic self-efficacy and academic success. However, while some studies stated that academic self-efficacy causes academic success of the students $[9,21$, 22], other studies claimed that academic success makes academic self-efficacy stronger $[10,23]$. If a student can perform a duty assigned to them without being overwhelmed, it might also mean that their academic motivation is also high. Students with lower levels of motivation may have difficulties in completing a difficult academic assignment, as a result their academic self-efficacy weakens [24].

The aim of this study is to determine whether academic self-efficacy of university students differ significantly in terms of gender, education variables (grade levels, perceived academic success in high school, perceived academic success in university, and major), and family related variables (education levels of the parents, income of the family, number of members and siblings in the family, and the dwelling unit where the student lived the longest), were also taken into consideration in this study.

\section{Materials and Methods}

\subsection{Participants}

This study was conducted on 1679 students who were chosen by proportion sampling method among 15708 students studying at Faculty of Pharmacy, Faculty of Literature, Faculty of Education, Faculty of Science, Faculty of Fine Arts, Faculty of Aviation and Space Sciences, Faculty of Architecture and Design, Faculty of Law, Faculty of Economics and Administrative Sciences, Faculty of Communication Sciences, Faculty of Engineering, and Faculty of Health Sciences. Of all the participants, 955 (57\%) were female, 724 (43\%) were male. $319(19 \%)$ were freshmen, $388(23 \%)$ were sophomores, 426 (25\%) were juniors, and 546 (32\%) were seniors. The age range of the participants was between 17-37, the average age was 21.31 , and the standard deviation of the ages was 2.04 .

\subsection{Instruments}

\subsubsection{Academic Self-Efficacy Scale (ASS)}

The ASS, which was developed by Jerusalem and Schwarzer [25], was translated into Turkish by Yllmaz, Gurcay and Ekici [26]. The ASS, which have 7 items (e.g. Even if a written exam is very hard, I know I will succeed) is one-dimension. The scale has 4-Likert type (1=Completely Disagree, $4=$ Completely Agree) rating. The scores that can be obtained from the scale range from 7 to 28 , and higher scores indicated that higher academic self-efficacy. Cronbach alpha coefficient of the Turkish version of the ASS was calculated as .79 [26]. In the current study, the Cronbach alpha coefficient of the scale was calculated as .73 .

\subsubsection{Personal Information Form (PIF)}

PIF was prepared by the first author, and includes four (e.g. How do you perceive your academic success?) questions related with educational situations (grade level, perceived academic success in high school, perceived academic success in university, and major). PIF also includes six questions (e.g. How is your family's economic situation?) associated with family-related situations (education level of the parents, economic situation of the family, number of members and siblings in the family, and the dwelling unit where the student lived the longest). In addition, gender was asked in the PIF. 


\subsection{Procedure}

The questionnaire packet used in the study were given to the students in one booklet and applied in one session in the classroom environment. Completion of the instruments required no more than five minutes.

In the analysis of the data, independent sample $t$ test and one-way ANOVA were used. Before statistical techniques were applied, the assumptions of the independent sample $t$ test and one-way ANOVA were checked. When one-way analysis of variance results were found statistically significant, Scheffe test was applied in order to find the sources of the differences between groups. In situations where variances were not homogenous, Dunnet $\mathrm{C}$ test was applied.

\section{Results}

Independent $\mathrm{t}$ test results showing whether there is a significant relationship between genders and academic self-efficacy of university students are shown in Table 1.

Table 1. $\mathrm{t}$ Test Result Comparing Males and Females on Academic Self-Efficacy

\begin{tabular}{|c|c|c|c|c|c|c|}
\hline Variable & Gender & $\mathbf{n}$ & $\bar{X}$ & sd & $\boldsymbol{t}$ & df \\
\hline $\begin{array}{c}\text { Academic } \\
\text { Self-efficacy }\end{array}$ & Male & 724 & 20.53 & 3.34 & \multirow{2}{*}{$5.47^{* *}$} & \multirow{2}{*}{1677} \\
\cline { 2 - 6 } & Female & 955 & 19.66 & 3.15 & & \\
\hline
\end{tabular}

$* * \mathrm{p}<.01$

As seen in Table 1, academic self-efficacy scores of males are higher than females. $t$ test results to test whether the difference observed between males and females is significant or not showed that the difference is statistically significant $\left[t_{(1677)}=5.47, p<.01\right]$.

One-way analysis of variance results showing whether self-efficacy of university students differ significantly according to their grade levels, perceived academic successes in high school and university, and their field of study are presented in Table 2 .

Table 2. ANOVAs Results for Academic Self-Efficacy by Educational Variables

\begin{tabular}{|c|c|c|c|c|c|c|c|c|c|c|}
\hline Variables & $\mathrm{n}$ & $\bar{X}$ & SD & Source & $\begin{array}{l}\text { Sum of } \\
\text { Squares }\end{array}$ & $\mathrm{df}$ & $\begin{array}{l}\text { Mean } \\
\text { Square }\end{array}$ & $F$ & $\eta^{2}$ & $\begin{array}{c}\text { Post Hoc } \\
\text { Comparison }\end{array}$ \\
\hline \multicolumn{11}{|c|}{ Grade level } \\
\hline Freshmen $^{\text {a }}$ & 319 & 20.03 & 3.29 & Between & & & & \multirow{4}{*}{$3.74^{*}$} & \multirow{4}{*}{.007} & \multirow{4}{*}{$\begin{array}{c}\text { (Scheffe) } \\
\mathrm{b}<\mathrm{d}\end{array}$} \\
\hline Sophomores ${ }^{\mathrm{b}}$ & 388 & 19.71 & 3.36 & Groups & 110.4 & 3 & 39.00 & & & \\
\hline Juniors $^{c}$ & 426 & 19.88 & 3.22 & \multirow{2}{*}{$\begin{array}{l}\text { Within } \\
\text { Groups }\end{array}$} & \multirow{2}{*}{17705.78} & \multirow{2}{*}{1675} & \multirow{2}{*}{10.57} & & & \\
\hline Seniors ${ }^{\mathrm{d}}$ & 546 & 20.38 & 3.17 & & & & & & & \\
\hline \multicolumn{11}{|c|}{ Perceived Academic Success in High School } \\
\hline Low $^{\mathrm{a}}$ & 137 & 19.87 & 3.63 & \multirow{2}{*}{$\begin{array}{c}\text { Between } \\
\text { Groups }\end{array}$} & \multirow{2}{*}{47.25} & \multirow{2}{*}{2} & \multirow{2}{*}{23.62} & \multirow{3}{*}{2.23} & \multirow{3}{*}{.003} & \multirow{3}{*}{ - } \\
\hline Middle $^{\mathrm{b}}$ & 411 & 19.77 & 3.15 & & & & & & & \\
\hline $\operatorname{High}^{c}$ & 1131 & 20.15 & 3.25 & $\begin{array}{l}\text { Within } \\
\text { Groups }\end{array}$ & 17777.02 & 1676 & 10.61 & & & \\
\hline \multicolumn{11}{|c|}{ Perceived Academic Success in University } \\
\hline Low $^{a}$ & 186 & 18.04 & 3.38 & \multirow{2}{*}{$\begin{array}{l}\text { Between } \\
\text { Groups }\end{array}$} & \multirow{2}{*}{1996.73} & \multirow{2}{*}{2} & \multirow{2}{*}{998.37} & \multirow{3}{*}{$105.72^{*}$} & \multirow{3}{*}{.112} & \multirow{3}{*}{$\begin{array}{c}\text { (Dunnett C) } \\
\mathrm{a}<\mathrm{b}<\mathrm{c}\end{array}$} \\
\hline Middle ${ }^{b}$ & 989 & 19.65 & 3.01 & & & & & & & \\
\hline High $^{c}$ & 504 & 21.52 & 3.07 & $\begin{array}{l}\text { Within } \\
\text { Groups }\end{array}$ & 15827.53 & 1676 & 9.44 & & & \\
\hline \multicolumn{11}{|c|}{ Field of Study } \\
\hline Tech \& Sci ${ }^{\text {a }}$ & 521 & 19.65 & 3.09 & \multirow{2}{*}{$\begin{array}{c}\text { Between } \\
\text { Groups }\end{array}$} & \multirow{2}{*}{169.37} & \multirow{2}{*}{3} & \multirow{2}{*}{56.46} & \multirow{4}{*}{$5.36^{*}$} & \multirow{4}{*}{.010} & \multirow{4}{*}{$\begin{array}{c}\text { (Scheffe) } \\
\mathrm{a}<\mathrm{b}\end{array}$} \\
\hline Social $^{\text {b }}$ & 1012 & 20.22 & 3.34 & & & & & & & \\
\hline Health $^{\mathrm{c}}$ & 80 & 19.49 & 3.18 & \multirow{2}{*}{$\begin{array}{l}\text { Within } \\
\text { Groups }\end{array}$} & \multirow{2}{*}{17654.90} & 1675 & 1054 & & & \\
\hline $\operatorname{Art}^{\mathrm{d}}$ & 66 & 20.77 & 3.16 & & & 1075 & 10.34 & & & \\
\hline
\end{tabular}

Notes. $* \mathrm{p}<.05$, Tech \& Sci $=$ Technical and Science 
As seen in Table 2, academic self-efficacy of university students differs significantly in terms of their grade levels, $F_{(3,1675)}=3.74, p<.05, \eta^{2}=.007$. Scheffe multiple comparison results showed that academic self-efficacy levels of senior year students $(M=20.38, S D=3.17)$ are significantly higher than sophomore-year students $(M=$ $20.38, S D=3.17)$. The results of analysis of variance pointed that academic self-efficacy do not differ significantly when perceived academic success in high school is considered $F_{(2,1676)}=2.23, p>.05, \eta^{2}=.003$. On the other hand, academic self-efficacy of university students differs significantly when perceived academic success in university is considered $F_{(2,1676)}=105.72, p<.01, \eta^{2}=.112$. Dunnet $\mathrm{C}$ multiple comparison test which was held in order to determine the sources of these differences, revealed that the differences in average points of those who perceive themselves as unsuccessful $(M=18.04, S D=3.38)$ and successful in medium level $(M=19.65, S D=3.01)$, and successful in medium level and successful $(M=21.52$, $S D=3.07)$ are statistically significant. Moreover, self-efficacy is found to differ significantly according to the field of study $F_{(3,1675)}=5.36, p<.05, \eta 2=.010$. Scheffe multiple comparison analysis results revealed that students who are studying in the field of social sciences $(M=20.22$, $S D=3.34$ ) have higher academic self-efficacy points when compared to students studying in fields of technical and physical sciences $(M=19.65, S D=3.09)$.

The results of One-way analysis of variance related to whether academic self-efficacy of university students significantly differ according to some variables related to family (education level of the parents, income of the family, number of members and siblings in the family, and the dwelling unit where the student lived the longest) are shown in Table 3.

Table 3. ANOVAs Results for Academic Self-Efficacy by Family-Related Variables

\begin{tabular}{|c|c|c|c|c|c|c|c|c|c|c|}
\hline Variables & $\mathrm{n}$ & $\bar{X}$ & SD & Source & $\begin{array}{c}\text { Sum of } \\
\text { Squares }\end{array}$ & $\mathrm{df}$ & $\begin{array}{l}\text { Mean } \\
\text { Square }\end{array}$ & $\mathrm{F}$ & $\eta^{2}$ & $\begin{array}{c}\text { Post Hoc } \\
\text { Comparison }\end{array}$ \\
\hline \multicolumn{11}{|c|}{ Education Level of Mother's } \\
\hline Illiterate $^{\mathrm{a}}$ & 100 & 20.38 & 3.41 & \multirow{3}{*}{$\begin{array}{l}\text { Between } \\
\text { Groups }\end{array}$} & \multirow{3}{*}{60.66} & \multirow{3}{*}{4} & \multirow{3}{*}{15.17} & \multirow{5}{*}{1.43} & \multirow{5}{*}{.003} & \multirow{5}{*}{ - } \\
\hline Primary Sch. ${ }^{\mathrm{b}}$ & 576 & 20.23 & 3.32 & & & & & & & \\
\hline El. Edu ${ }^{\mathrm{c}}$ & 316 & 19.8 & 3.01 & & & & & & & \\
\hline High Sch $^{\mathrm{d}}$ & 432 & 19.91 & 3.24 & Within & \multirow{2}{*}{17763.59} & \multirow{2}{*}{1674} & \multirow{2}{*}{10.61} & & & \\
\hline University $^{\mathrm{e}}$ & 255 & 19.94 & 3.37 & Groups & & & & & & \\
\hline \multicolumn{11}{|c|}{ Education Level of Father's } \\
\hline Illiterate $^{\mathrm{a}}$ & 28 & 20.86 & 2.96 & \multirow{3}{*}{$\begin{array}{c}\text { Between } \\
\text { Groups }\end{array}$} & \multirow{3}{*}{52.38} & \multirow{3}{*}{5} & \multirow{3}{*}{10.48} & \multirow{6}{*}{.99} & \multirow{6}{*}{.003} & \multirow{6}{*}{ - } \\
\hline Primary Sch. ${ }^{b}$ & 343 & 20.23 & 3.47 & & & & & & & \\
\hline Elemntr. $\mathrm{Edu}^{\mathrm{c}}$ & 306 & 20.15 & 3.05 & & & & & & & \\
\hline High Sch $^{\mathrm{d}}$ & 536 & 19.91 & 3.23 & \multirow{3}{*}{$\begin{array}{l}\text { Within } \\
\text { Groups }\end{array}$} & \multirow{3}{*}{17771.88} & \multirow{3}{*}{1673} & \multirow{3}{*}{10.62} & & & \\
\hline University $^{\mathrm{e}}$ & 440 & 19.9 & 3.29 & & & & & & & \\
\hline Master/PhD ${ }^{\mathrm{f}}$ & 26 & 19.88 & 3.11 & & & & & & & \\
\hline \multicolumn{11}{|c|}{ Perceived economic situation in family } \\
\hline Low $^{\text {a }}$ & 62 & 20.42 & 3.73 & Between & & & & \multirow{3}{*}{$3.01^{*}$} & \multirow{3}{*}{.004} & \\
\hline Middle $^{\mathrm{b}}$ & 1051 & 19.88 & 3.21 & Groups & 63.85 & 2 & 31.92 & & & (Scheffe) \\
\hline $\operatorname{High}^{\mathrm{c}}$ & 566 & 20.27 & 3.27 & $\begin{array}{l}\text { Within } \\
\text { Groups }\end{array}$ & 17760.42 & 1676 & 10.60 & & & $\mathrm{~b}<\mathrm{c}$ \\
\hline & & & & Numbe & individuals & he fam & & & & \\
\hline $2^{\mathrm{a}}$ & 142 & 20.03 & 3.17 & & & & & & & \\
\hline $3^{b}$ & 339 & 19.93 & 3.09 & Between & 13.45 & 4 & 3.36 & & & \\
\hline $4^{\mathrm{c}}$ & 656 & 20.14 & 3.32 & & & & & .32 & .003 & - \\
\hline $5^{\mathrm{d}}$ & 319 & 19.94 & 3.22 & Within & & & & & & \\
\hline 6 and upper $^{\mathrm{e}}$ & 223 & 19.99 & 3.44 & Groups & 17810.82 & 1674 & 10.64 & & & \\
\hline & & & & & imber of sit & & & & & \\
\hline $1^{\mathrm{a}}$ & 114 & 19.66 & 3.22 & & & & & & & \\
\hline $2^{b}$ & 803 & 20 & 3.19 & Between & 48.61 & 5 & 9.72 & & & \\
\hline $3^{c}$ & 432 & 20.02 & 3.35 & & & & & & & \\
\hline $4^{d}$ & 163 & 20.47 & 3.16 & & & & & 91 & .003 & - \\
\hline $5^{\mathrm{e}}$ & 64 & 20.14 & 3.35 & Within & 17775.66 & 1673 & 10.62 & & & \\
\hline 6 and upper ${ }^{f}$ & 103 & 19.96 & 3.54 & & & & & & & \\
\hline & & & & velling unit & ere the stud & lived th & gest & & & \\
\hline City $^{\mathrm{a}}$ & 1130 & 20.09 & 3.26 & Between & & & & & & \\
\hline County $^{b}$ & 391 & 19.94 & 3.35 & Groups & 16.426 & 3 & 5.47 & 51 & 001 & \\
\hline Town $^{c}$ & 59 & 19.91 & 3.25 & Within & & & & .51 & .001 & - \\
\hline Village $^{\mathrm{d}}$ & 99 & 19.76 & 2.93 & Groups & 17807.83 & 1675 & 10.63 & & & \\
\hline
\end{tabular}

Notes. $* \mathrm{p}<.05, \mathrm{Sch}=$ School, El. Edu= Elementary Education 
As seen in Table 3, academic self-efficacy of university students does not significantly differ in terms of mother's level of education $\left[F_{(4,1674)}=1.43, p>.05, \eta^{2}=.003\right]$, father's level of education $\left[F_{(5,1673)}=.99, p>.05, \eta^{2}=.003\right]$, the number of family members $\left[F_{(4,1674)}=.32, p>.05\right.$, $\left.\eta^{2}=.003\right]$, number of siblings $\left[F_{(5,1673)}=.91, p>.05\right.$, $\left.\eta^{2}=.003\right]$, and the dwelling unit where the student lived the longest $\left[F_{(3,1675)}=.51, p>.05, \eta^{2}=.001\right]$. On the other hand, academic self-efficacy of students significantly differs in terms of income of the family, $F_{(5,1673)}=3.01$, $p<.05, \eta^{2}=.004$. Scheffe multiple comparison test results revealed that academic self-efficacy levels of students with higher levels of economical perception $(M=20.27$, $S D=3.27)$ are significantly higher than the ones having middle level economical perception $(M=19.88, S D=3.21)$.

\section{Discussion}

In this study, whether academic self-efficacy of university students differ statistically significant or not in terms of various educational and family-related variables was investigated. The finding of this study that academic self-efficacy of male students is higher than females is consistent with the results of some of the studies in the related literature $[27,28]$. On the other hand, the findings contradict with some of the studies claiming that academic self-efficacy of female students is higher than males [29, 30]. The results of the study point that the relationship between the academic self-efficacy of males and females is ambiguous. Whether females or males are more advantageous in academic self-efficacy-gender relationship will be made clear by the future studies.

Although we got the impression that academic self-efficacy gets significantly higher in upper classes when senior students presented higher academic self-efficacy compared to sophomores, there was no significant difference in all other grade levels. As a matter of fact, there are ambiguous results consistent with this study. While some studies suggest that academic self-efficacy gets higher in upper grade levels [27, 31], some others claimed that as the grade levels get lower, academic self-efficacy of the students lower accordingly [17].

The finding of this study suggesting that there is no significant difference between perceived high school success of university students and their academic self-efficacy is inconsistent with similar studies in the literature. When the literature is explored, it is seen that previous success of students affects their self-efficacy positively. According to Bujack [32], students' academic successes until their high school life, shape their academic self-efficacy positively in their current educational duties. Moreover, Bandura [1] states that the most important factor contributing to shape self-efficacy are past successes, and emphasizes the importance of past successes of students on academic self-efficacy. In this respect, it would be wise to indicate that this finding of the study is not an expected result, and it is open to question.

The finding of the study, claiming that academic self-efficacy of the students who perceive themselves successful is higher when compared to students who perceive themselves unsuccessful, or their success is on average, reveals that the level of individuals' successes is an important factor in raising the perception of academic self-efficacy. As a matter of fact, this finding, which is an expected result for the relation between academic success and academic self-efficacy is in parallel with similar studies in the literature $[9,10,21,23,33]$.

It is seen in the study that academic self-efficacy of social sciences students is higher when compared to students of faculty of health sciences, fine arts, technique and physical sciences. Although the number of studies in the literature is scarce, there is partial parallelism of the results of this study with the results of the study conducted by Ozsüer, Inan, Uyanık, and Ergün's [34] study.

Although it is thought that when education level of parents is higher, they pay more attention to the education of their children, thus academic self-efficacy of the students will be higher [35], the results of this study does not confirm this perception. Moreover, it is found in this study that the children of illiterate parents have higher academic self-efficacy when compared to academic self-efficacy of other students. However, this finding of the study is consistent with Millburg's [36] remarks that negative environmental effects could enhance academic self-efficacy. As illiterate parents supported their children's' successes since they had the chance to make a difference, they probably contribute to their children's academic self-efficacy positively.

In the study, it is also found that academic self-efficacy of students with middle level economic situation of the family is lower than the ones with higher-level economic situation of the family. This finding of the study suggest that since students with higher economic situation of the family have more qualified education opportunities, and have more qualified education experiences, this possibly strengthen their academic self-efficacy. As a matter of fact, this result of the study is consistent with a similar study [37] in the literature.

Another finding of the study stating that the number of the family members do not have any effect on academic self-efficacy of university students is inconsistent with studies in the literature claiming that the larger the family, the higher the academic self-efficacy of the individual [5]. However, it could also be considered that when the number of family members increases, the attention that the individual could have in a small family will be lower, and this could result in lower academic self-efficacy of the student.

It was determined in the study that academic self-efficacy of the students does not differ according to the number of siblings they have. In other words, having one or more siblings does not mean to be advantageous in academic self-efficacy. Since having more siblings mean to have 
more family members, it is understandable for the finding of this study to be in parallel with the finding related to the number of family members.

Since there is no statistically significant difference between academic self-efficacy of university students and the dwelling unit they lived the longest suggest that there are no relations between the dwelling unit and academic self-efficacy of individuals. This might also suggest that it is not the place but whether the individual had positive or negative experiences in the place, might be more determinative for academic self-efficacy.

If it is necessary to indicate one important limitation of the study, the sample of the study consists only of students who were studying in Anadolu University at the time. In this respect it would be inconvenient to generalize the study results to all the university students.

As a result, it is seen that academic self-efficacy of university students differs significantly in terms of various educational and family related variables. Hence, conferences to emphasize the importance of academic self-efficacy could be held for academicians, teachers and parents. This way their awareness on the subject could be raised. Additionally, psychoeducational programs could be structured for students to raise their academic self-efficacy levels.

\section{REFERENCES}

[1] A. Bandura. Self-efficacy: The exercise of control. W.H. Freeman, New York, 1997.

[2] S. L. Anderson, \& N. E. Betz. Sources of social self-efficacy expectations: Their measurement and relation to career development. Journal of Vocational Behavior, 58(1), 98-117, 2001.

[3] J. Barlow, C. Wright, \& L. Cullen. A job-seeking self-efficacy scale for people with physical disabilities: Preliminary development and psychometric testing. British Journal of Guidance \& Counseling, 30(1), 37-53, 2002.

[4] H. J. Mayall. Differences in gender based technology self-efficacy across academic levels. International Journal of Instructional Media 35(2), 145-156, 2008.

[5] D. H. Schunk, \& F. Pajares. (2001). The development of academic self-efficacy. In A. Wigfield \& J. Eccles (Eds.), Development of achievement motivation, Academic Press, Inc. San Diego, 2001.

[6] P. T. Tutor. Factors influencing nursing students' motivation to succeed. Unpublished Doctoral Dissertation, University of Southern California, USA, 2008.

[7] S. R. Banfield. How do college/university teacher misbehaviors influence student cognitive learning, academic self-efficacy, motivation, and curiosity? Unpublished Doctoral Dissertation, West Virginia University, USA, 2009.

[8] S. D. Kemp. Academic self-efficacy and middle school students: A study of advisory class teaching strategies and academic self-efficacy. Unpublished Doctoral Dissertation, La Sierra University, USA, 2011.

[9] P. A. Gore. Academic self-efficacy as a predictor of college outcomes: Two incremental validity studies. Journal of Career Assessment, 14, 92-115, 2006.

[10] M. M. Chemers, L. Hu, \& B. F. Garcia. Academic self-efficacy and the first-year college student performance and adjustment. Journal of Educational Psychology, 93(1), 55-64, 2001.

[11] H. Margolis, \& P. P. McCabe. Self-efficacy: A key to improving the motivation of struggling learners. The Clearing House, 77(6), 241-249, 2004.

[12] B. J. Zimmerman. Self-efficacy: An essential motive to learn. Contemporary Educational Psychology, 25, 82-91, 2000.

[13] D. H. Schunk. Self-efficacy and classroom learning. Psychology in the Schools, 22(2), 208-223, 1985.

[14] K. R. Lodewyk, \& P. H. Winne. Relations among the structure of learning tasks, achievement, and changes in self-efficacy in secondary students. Journal of Educational Psychology, 97(1), 3-12, 2005.

[15] M. Bassi, P. Steca, A. D. Fave, \& G. V. Caprara. Academic self-efficacy beliefs and quality of experience in learning. Journal of Youth and Adolescence, 36, 301-312, 2007.

[16] F. Pajares. Self-efficacy beliefs in academic settings. Review of Educational Research, 66(4), 543-578, 1996.

[17] A. L. Wuebbels. The development of a social emotional and academic self-efficacy curriculum for sixth grade adolescent students. Unpublished Doctoral Dissertation, School of Saint Louis University, USA, 2006.

[18] S. Poyrazli, C. Arbona, A. Nora, B. McPherson, \& S. Pisecco. Relation between assertiveness, academic self-efficacy, and psychosocial adjustment among international graduate students. Journal of College Student Development, 43, 632-642, 2002

[19] Y. Nie, S. Lau, \& A. Liau. Role of academic self-efficacy in moderating the relation between task importance and test anxiety. Learning and Individual Differences, 21, 736-741, 2011.

[20] H. Chung, \& M. Elias. Patterns of adolescent involvement in problem behaviors: Relationship to self-efficacy, social competence and life events. American Journal of Community Psychology, 24, 771-784, 1996.

[21] S. M. Elias, \& S. MacDonald. Using past performance, proxy efficacy and academic self-efficacy to predict college performance. Journal of Applied Social Psychology, 37(11), 2518-2531, 2007.

[22] E. Hejazi, M. Shahraray, M. Farsinejad, \& A. Asgary. Identity styles and academic achievement: Mediating role of academic self-efficacy. Social Psychology of Education, 12, 123-135, 2009.

[23] Y. J. Joo, M. Bong, \& H. J. Choi. Self-efficacy for self-regulated learning, academic self-efficacy, and Internet self-efficacy in Web-based instruction. Educational Technology Research and Development, 48, 5-17, 2000. 
[24] 24. A. Bandura. Perceived self-efficacy in cognitive development and functioning. Educational Psychology, 28, 117-148, 1993.

[25] M. Jerusalem, \& R. Schwarzer. Fragebogen zur Erfassung von "Selbstwirksamkeit. Skalen zur Befindlichkeit und Personenlichkeit In R. Schxarzer (Ed.). Freie Universitaet, Institut fer Psychologie, Berlin, 1981.

[26] M. Yılmaz, D. Gürçay, \& G. Ekici. Akademik Özyeterlik Ölçeğinin Türkçe'ye uyarlanması [Adaptation of the Academic Self-Efficacy Scale to Turkish]. H. U. Journal of Education, 33, 253-259, 2007.

[27] S. Altunsoy, O. Çimen, G. Ekici, A. D. Atik, \& A. Gökmen. An assessment of the factors that influence biology teacher candidates' levels of academic self-efficacy. Procedia Social and Behavioral Sciences, 2, 2377-2382, 2010.

[28] J. Zhoa, J. McCormick, \& K. Hoekman. Idiocentrism-allocentrism and academics' self-efficacy for research in Beijing universities. International Journal of Educational Management, 22(2), 168-183, 2008.

[29] N. Dentlinger. Academic self-efficacy, prior academic success, demographic variables, and academic success in first semester associate degree nursing coursework. Unpublished Master Thesis, University of Oklahoma, USA, 2003.

[30] H. J. Mayall. An exploratory/descriptive look at gender differences in technology self-efficacy and academic self-efficacy in the globaled project. Unpublished Doctoral Dissertation, University of Connecticut, USA, 2002.

[31] K. F. Johnson. The influence of school connectedness and academic self-efficacy on self-reported norm related

\footnotetext{
${ }^{i}$ This study was based on Seydi Ahmet SATICI's (2013) master thesis entitled "Üniversite Öğrencilerinin Akademik Öz-yeterliklerinin Çeşitli Değişkenler Açısından Incelenmesi" under Gurhan CAN's supervision at Graduate School of Educational Sciences, Anadolu University, Turkey.
}

pro-social behavior. Unpublished Doctoral Dissertation, Pennsylvania State University, USA, 2011.

[32] L. K. Bujack. Predicting student persistence in adult basic education using interaction effects among academic self-efficacy and students participation and academic variables. Unpublished Doctoral Dissertation, Capella University, USA, 2012.

[33] A. Zajacova, S. M. Lynch, \& T. J. Espenshade. Self-efficacy, stress, and academic success in college. Research in Higher Education, 46(6), 677-706, 2005.

[34] S. Özsüer, G. İnal, Ö. Uyanık, \& M. Ergün. Afyon Kocatepe Üniversitesinde öğrenim gören öğrencilerin akademik özyeterlik inanç düzeylerinin incelenmesi [Investigation academic self-efficacy belief levels of students being taught at Afyon Kocatepe University]. AKÜ Sosyal Bilimler Dergisi, 13(2), 113-125, 2011

[35] W. Fan, \& C. M. Williams. The effects of parental involvement on students' academic self-efficacy, engagement and intrinsic motivation. Educational Psychology: An International Journal of Experimental Educational Psychology, 30(1), 53-74, 2010.

[36] S. N. Millburg. The effects of environmental risk factors on at-risk urban high school students' academic self-efficacy. Unpublished Doctoral Dissertation, University of Cincinnati, USA, 2009.

[37] Y. Tong, \& S. Song. A study on general self-efficacy and subjective well-being of low SES college students in a Chinese university. College Student Journal, 38(4), 637-642, 2004. 